DOI: https://doi.org/10.34069/AI/2021.44.08.29

How to Cite:

Ostrohliad, O., Torbas, O., Zavtur, V., Sydorchuk, V., \& Fedoriv, O. (2021). Effectiveness standards for investigation of corruption crimes: Theory and practice. Amazonia Investiga, 10(44), 295-306. https://doi.org/10.34069/AI/2021.44.08.29

\title{
Effectiveness standards for investigation of corruption crimes: Theory and practice
}

\section{Стандарти ефективності розслідування корупційних злочинів: теорія і практика}

Received: July 13, 2021

Accepted: September 10, 2021

\begin{abstract}
The article deals with development of a doctrinal system of effectiveness standards for the investigation of corruption crimes. The study used a number of philosophical, general scientific and specific methods of gaining scientific knowledge, including: dialectical method, hermeneutic method, method of systemic and structural analysis, methods of analysis and synthesis, functional method, formal legal method and modeling method. It is proposed to define the investigation effectiveness as the feature of pre-trial investigation, which is characterized by the ability to achieve the tasks envisioned in Art. 2 of the CPC of Ukraine (Law No. 4651-VI, 2012) and can be assessed by checking the number of objectively necessary procedural actions and the effectiveness of making intermediate and final procedural decisions. It is emphasized that the general standards of investigation effectiveness, formulated by the case law of the ECHR, are partially taken into account in Art. 2 of the CPC of Ukraine (Law No. 4651-VI, 2012) through stating the need of investigation being efficient, complete and impartial. The authors formulate scientific approaches to determining the main criteria for the
\end{abstract}

Анотація

Метою статті $\epsilon$ формування доктринальної системи стандартів ефективності розслідування корупційних злочинів. У ході дослідження було використано низку філософських, загальнонаукових та спеціально-наукових методів наукового пізнання, серед яких: діалектичний метод, герменевтичний метод, метод системно-структурного аналізу, методи аналізу та синтезу, функціональний метод, формально-юридичний метод та метод моделювання. Під ефективністю розслідування запропоновано розуміти ознаку досудового розслідування, яка характеризується можливістю досягнути завдання, які передбачені ст. 2 КПК України, та яка може бути оцінена шляхом перевірки кількості проведених об'єктивно необхідних процесуальних дій та оперативністю прийняття проміжних і кінцевих процесуальних рішень. Наголошено, що загальні стандарти ефективності розслідування, сформульовані прецедентною практикою ЄСПЛ частково враховано у ст. 2 КПК України через завдання швидкого, повного та неупередженого розслідування. Сформульовано наукові підходи

\footnotetext{
${ }^{120}$ Ph.D in Law, Associate Professor of Law and Law enforcement activity Department, State University "Zhytomyr Polytechnic", Zhytomyr, Ukraine.

${ }^{121} \mathrm{Ph} . \mathrm{D}$ in Law, Associate Professor of Criminal Procedure, Detective and Operational-Search Activity Department, National University “Odesa Law Academy”, Odesa, Ukraine.

${ }^{122} \mathrm{Ph} . \mathrm{D}$ in Law, Senior Lecturer of Criminal Procedure, Detective and Operational-Search Activity Department, National University «Odesa Law Academy», Odesa, Ukraine.

${ }^{123} \mathrm{PhD}$ student of Criminal Procedure, Detective and Operational-Search Activity Department, National University «Odesa Law Academy», Odesa, Ukraine.

${ }^{124} \mathrm{PhD}$ student of the Department of Criminal Law Disciplines, Institute of Law, Lviv State University of Internal Affairs, Lviv, Ukraine.
} 
effectiveness of pre-trial investigation of corruption crimes.

Key words: criminal proceeding, tasks of a criminal proceeding, pre-trial investigation, standards of investigation, investigation effectiveness, investigation of corruption crimes.

\section{Introduction}

One of the tasks of criminal proceedings in Ukraine is to ensure an efficient, complete and impartial investigation so that everyone who commits a criminal offense is prosecuted to the extent of their guilt, no innocent person is charged or convicted, no person is subjected to unreasonable procedural pressure, and that the proper legal procedure be applied to each participant in the criminal proceedings (Art. 2 of the Criminal Procedure Code (CPC) of Ukraine (Law No. 4651-VI, 2012)). Apparently, the legislator has programmatically defined three standards of pre-trial investigation: speed, completeness and impartiality. At the same time, European standards of pre-trial investigation, in particular, are formulated in the case law of the European Court of Human Rights on the positive obligations of the state under Art. 2 and Art. 3 of the Conventionand contain broader wording that recognizes the effectiveness standards of pre-trial investigation.

During the investigation of certain types of criminal offenses, some additional standards of pre-trial investigation may arise under consideration of some peculiarities of these offenses. The creation of special standards for pre-trial investigation of various categories of criminal offenses, on the one hand, will contribute to a more complete, fast and impartial pre-trial investigation, and on the other hand, will become a criterion for assessing the effectiveness of such investigations, which in turn will allow efforts to improve it, which will generally contribute to the inevitability of punishment of perpetrators. Corruption-related criminal offenses are no exception in this context. Thus, their latency, significant negative economic, political and social impact on the individual, society and the state as a whole have become the basis for increasing complexity of existing standards of pre-trial investigation and the development of new ones.

The purpose of this study is to identify the effectiveness standards for investigation of corruption crimes in theoretical and practical aspects. до визначення основних критеріїв ефективності досудового розслідування корупційних злочинів.

Ключові слова: кримінальне провадження, завдання кримінального провадження, досудове розслідування, стандарти розслідування, ефективність розслідування, розслідування корупційних злочинів.

\section{Theoretical Framework or Literature Review}

Issues of the pre-trial investigation effectiveness were researched by: Znikin (2014), Stetsenko (2018), Korcheva (2019); Hovorun (2013); Sichko (2021); Chernobaiev (2020); Akhtyrska, Kasko, Malanchuk, Melikian, Poshva, Fulei, Shuklina (2011); Bielousov, Hatiiatullin, Zaporozhtsev, Tarasova, Shurduk (2018); Hnatovskyi, Bielousov, Shvets, Venher, Bondarenko (2016), Hloviuk (2016); Lazukova (2018), and others. The issues of investigation of corruption crimes were researched by Zhidkov (2019), Burbelo (2015), Danyliuk (2011), Kymlyk (2014), Kymlyk (2017), Zhuravel and Reznikova (2017) and others.

Korcheva (2019) defined the concept of "the pretrial investigation effectiveness" as the duty of subjects conducting criminal proceedings at the stage of pre-trial investigation to solve the problems of criminal proceedings, to ensure comprehensiveness, completeness and impartiality of the investigation of criminal proceedings conditions as well as the priority of human rights and freedoms.

Znikin (2014) suggests that the definition of the pre-trial investigation effectiveness as the level of achievement of goals and objectives of the preliminary investigation stage as a result of legal, reliable, economic, optimal and rational organizational and procedural actions of the inquiry officer, investigator, prosecutor, head of the investigative department, and head of the investigative authority.

Stetsenko (2018) argued that the pre-trial investigation effectiveness is a value that has to be created. Instead, the ineffectiveness of the pretrial investigation means that the results of the pre-trial investigation are absent or lacking which indicates that the investigators have not gathered sufficient evidence to solve the crime.

After considering the criteria for pre-trial investigation in terms of the case law of the European Court of Human Rights, Hovorun (2013) noted that these criteria should be recognized as universal for determining the pre- 


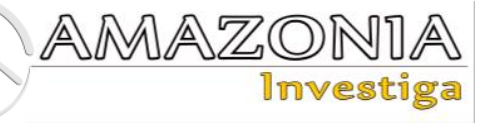

trial investigation effectiveness in all categories of cases.

Sichko (2021) identified the following standards of the pre-trial investigation effectiveness: a) independence and impartiality; b) public control (or publicity); c) reasonable speed (or efficiency); d) proper persistence, diligence; e) accuracy.

Chernobaiev (2020) singled out the criteria for an effective pre-trial investigation in accordance with the case law of the European Court of Human Rights: focus on achieving the objectives of criminal proceedings; legality; publicity; reasonable speed; comprehensiveness and completeness of the investigation; independence and impartiality; transparency; individualization; differentiation of forms of investigation.

Akhtyrska, Kasko, Malanchuk, Melikian, Poshva, Fulei, and Shuklina (2011) disclosed the provisions of the investigation into the facts of ill-treatment by law enforcement agencies of Ukraine (based on the decisions of the European Court of Human Rights in cases against Ukraine); analyzed judicial practice through the lens of compliance with the conventional requirements of the absolute prohibition of torture and other cruel, inhuman or degrading treatment or punishment in Ukraine; discussed the application of the ECHR provisions and the case law of the European Court of Human Rights in the field of combating ill-treatment and impunity by the national courts of Ukraine.

Bielousov, Hatiiaullin, Zaporozhtsev, Tarasova, Shurduk (2018) analyzed the legislation on the recording and investigation of torture in places of detention.

Hnatovskyi, Bielousov, Shvets, Venher, Bondarenko (2016) considered the implementation of international standards in the field of prevention of ill-treatment in the criminal justice bodies of Ukraine, including in terms of the procedural role of the police, prosecutors, courts.

Hloviuk (2016) considered the relationship between the provisions of Art. 206 of the CPC of Ukraine (Law No. 4651-VI, 2012) and the investigation of ill-treatment.

Lazukova (2018) disclosed the minimum international legal requirements for due process in criminal proceedings during an emergency.
Zhidkov (2019) researched theoretical and practical problems of criminal procedural status of the detectives of the National Anti-Corruption Bureau of Ukraine. The essence and content of the powers of the detective of the National AntiCorruption Bureau of Ukraine, as the party of prosecution in criminal procedings were determinated.

Burbelo (2015) researched problems of investigation of corruption crimes by investigators as well as the elements of forensic characterization of corruption crimes.

Danyliuk (2011) researched tasks of an investigator during the subsequent stage of investigation of corruption crimes and its features are considered.

Kymlyk (2014) researched issues of planning the investigation of corruption crimes. The basic principles of planning are analyzed. The main role of planning during the investigation of corruption crimes was defined, and the internal structure of planning process was revealed.

Kymlyk (2017) researched aspects of human rights that may be actualized during the investigation of corruption crimes. The main ones are processed situations that pose a threat of violation or restriction of human rights and ways to avoid it taking into account the provisions of the CPC of Ukraine (Law No. 4651-VI, 2012).

Zhuravel and Reznikova (2017) researched forensic issues of ensuring the investigation of corruption crimes, which have a complex legal essense and cover forensic, tacticalorganizational and criminological aspects, and can be solved by developing theoretical foundations as well as scientific and practical recommendations for the investigation of corruption crimes.

\section{Methodology}

The methodological basis of the scientific study of the effectiveness standards of the investigation of corruption crimes consists of a set of philosophical, general scientific and specific methods of gaining scientific knowledge, including: dialectical method, hermeneutic method, method of systemic and structural analysis, methods of analysis and synthesis, functional method, formal legal method and modeling method.

The dialectical method was used for the scientific consideration of the effectiveness of pre-trial 
investigation as a doctrinal category, identification of contradictions in its content, the study of the dynamics of development of scientific thought on the system of investigation standards.

The use of the hermeneutic method allowed deepening the conceptual apparatus of scientific research, establishing the main approaches to the interpretation of the concept of "investigation effectiveness" in domestic and foreign doctrine, as well as in the case law of the ECHR. The article covers the author's approach to the content of the corresponding scientific category. Using the method of systemic structural analysis allowed revealing the main elements of the content of the concept of investigation effectiveness and establishing the correlations between them.

The use of methods of analysis and synthesis allowed determining the general system of effectiveness standards for the pre-trial investigation based on analysis of doctrinal sources and practice of the European Court of Human Rights as well as establishing its acceptability in the context of investigation of corruption crimes.

The use of the functional method allowed determining the scientific significance of establishing the effectiveness standards for the investigation of corruption crimes in order to increase the effectiveness of their investigation. The formal legal method was used in the study of the provisions of the criminal procedure legislation of Ukraine and the relevant practice of the European Court of Human Rights.

The modeling method was used for the formulation of doctrinal standards for the effectiveness of the investigation of corruption crimes, which is carried out by the National AntiCorruption Bureau of Ukraine.

\section{Results and Discussion}

General issues of effectiveness standards for the pre-trial investigation in the context of ECHR practice

In the CPC of Ukraine (Law No. 4651-VI, 2012), the term "effectiveness" in relation to pre-trial investigation is used in Art. 36, 37, 38, 39, 39-1, although the corresponding requirement is not formulated in Art. 2 or 3 of the CPC of Ukraine (Law No. 4651-VI, 2012). However, in practice, the ECHR has derived and has established a number of provisions that are considered as standards for the pre-trial investigation effectiveness at this stage.

In particular, in the case of Kholodkov and Kholodkova v. Ukraine (2015), the ECHR reiterates that the the obligation to protect the right to life under Article 2 of the Convention, read in conjunction with the State's general duty under Article 1 of the Convention to "secure to everyone within [its] jurisdiction the rights and freedoms defined in [the] Convention" requires by implication that there should be some form of effective official investigation when individuals have been killed as a result of the use of force. The essential purpose of such an investigation is to secure the effective implementation of the domestic laws which protect the right to life. What form of investigation will achieve this purpose may vary in different circumstances. However, whatever mode is employed, the authorities must act of their own motion once the matter has come to their attention. They cannot leave it to the initiative of the next of kin either to lodge a formal complaint or to take responsibility for the conduct of any investigatory procedure. This is not an obligation of result, but of means. The authorities must have taken all reasonable steps to secure the evidence concerning the incident. Any deficiency in the investigation which undermines its ability to establish the cause of death or the persons responsible will risk falling foul of this standard. There is also a requirement of promptness and reasonable expedition implicit in this context. It must be accepted that there may be obstacles or difficulties which prevent progress in an investigation in a particular situation. However, a prompt response by the authorities in investigating the use of lethal force or a disappearance may generally be regarded as essential in ensuring public confidence in their maintenance of the rule of law and in preventing any appearance of collusion in or tolerance of unlawful acts (p. 32, 33).In the case of the Kaverzin v. Ukraine (2012), the Court reiterates that Article 3 of the Convention requires that an investigation into arguable allegations of illtreatment must be thorough. This means that the authorities must always make a serious attempt to find out what happened and should not rely on hasty or ill-founded conclusions in order to close their investigation or as the basis of their decisions. They must take all reasonable steps available to them to obtain evidence concerning the incident, including, inter alia, eyewitness testimony and forensic evidence. The investigation should be capable of leading to the identification and punishment of those responsible. Otherwise, the general legal 


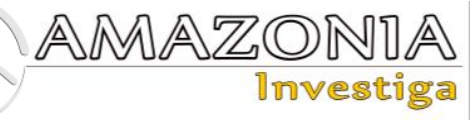

prohibition of torture and inhuman and degrading treatment and punishment would, despite its fundamental importance, be ineffective in practice and it would be possible in some cases for agents of the State to abuse the rights of those within their control with virtual impunity (p. 108, 109). The decision Yaremenko v. Ukraine (2008) states that the investigation must be independent, impartial and subject to public scrutiny, and that the competent authorities must act with exemplary diligence and promptness (p. 64). Thus, as can be seen even from these three quotations (although these approaches are now well-established practice), the ECHR has developed the following standards of effectiveness: the obligation to take action; ex officio response; preservation of evidence; efficiency and reasonable speed; good faith (diligence); impartiality; accessibility for the public and stakeholders (including victims).

At present, these standards must be taken into account in the conduct of pre-trial investigation in general, given the provisions of Art. 17 of the Law of Ukraine On the Implementation of Decisions and Application of the Case Law of the European Court of Human Rights (Law No. 3477-IV, 2006) and Part 5 of Art. 9 of the CPC of Ukraine (Law No. 4651-VI, 2012).

\section{Effectiveness standards for the pre-trial investigation in accordance with the requirements of the criminal procedure legislation of Ukraine}

The problem of the the pre-trial investigation effectiveness has been studied for a long time by both scientists and practitioners. This attention is explained primarily by the impossibility of using uniform objective indicators to assess the pretrial investigation effectiveness. In fact, the pretrial investigation effectiveness is a clear example of the concept of evaluation in criminal proceedings, and the nature and criteria of its definition may vary depending on the circumstances of each criminal case and the entity conducting the evaluation. However, this does not mean that legal doctrine has not attempted to develop such criteria.

For example, Zelenetskyi and Loboiko (2009) distinguish the following criteria:the degree of achieving the purpose of the prosecution activity by the bodies carrying out the criminal prosecution;relevance;legality;speed of criminal prosecution.

This position can be considered justified, because each of these criteria really allows saying that the pre-trial investigation is carried out effectively.
However, the problem is that in fact each of these criteria is evaluative as well, which does not always allow a realistic assessment of the pre-trial investigation effectiveness. Even the requirement of legality, which is based solely on the obligation to strictly comply with the requirements of criminal procedure law, may also be subject to different assessments by the relevant participants in the criminal proceedings. The lack of pre-trial investigation results will not always indicate the low effectiveness of the pretrial investigation. The ECHR noted that the state must first ensure an adequate response from law enforcement agencies in the investigation of criminal offenses, which consists in the efficient implementation of all possible procedural actions to solve the crime. However, this not always results in acquiring the information that will indicate the event of a criminal offense or the person who committed it. In this case, the main thing is that such actions are performed. In fact, this is the position that can be taken as a basis for establishing the criteria for pre-trial investigation.

The head of the body of inquiry, pre-trial investigation and the prosecutor must first assess how many procedural actions have been performed by the investigator or inquiry officer to investigate the corresponding criminal offense. It is impossible to set a certain minimum number in this case, but there must still be an adequate ratio between the time during which the pre-trial investigation continues and the number of procedural actions performed by the authorized person. This should take into account not only the number of such actions, but also their nature, because even if the interrogation does not require significant time, then the conduct of most covert investigative measures requires considerable time both in preparation and implementation. Therefore, it is proposed to estimate not the number of investigative and covert investigative measures that were carried out, but the number of all procedural actions that may include actions to prepare for the main public and covert investigative measures. While conducting them, the investigator or inquiry officer may not achieve the results sufficient to notify the person of the suspicion or to send the criminal information to court. However, the supervisor will establish that the investigator or inquiry officer has taken all the procedural steps necessary to obtain evidence.

During the pre-trial investigation, there is quite often a situation in which it is impossible to conduct new procedural actions at a certain stage of the pre-trial investigation until the completion 
of those that have already been initiated. For example, the further course of the pre-trial investigation may depend on the results of the ongoing covert investigative measures or on the results of the examination proceedings, which requires a lot of time. In this case, the number of procedural actions will be minimal, and this situation will take place regardless of the will of the investigator. In this case, the head of the body of inquiry or pre-trial investigation must assess the effectiveness of the pre-trial investigation by establishing:

1) whether the investigator (inquiry officer) really can not carry out any other procedural actions. The head must assess whether the authorized official can continue to collect evidence without waiting for the results of a certain procedural action, which takes a long time. It is possible that at this stage other investigative leads should be checked in case of negative results of the relevant procedural actions, or the investigator (inquiry officer) can predict which further evidence will need to be obtained and begin preparations for their reception;

2) whether the investigator (inquiry officer) can expedite the ongoing proceedings. In some cases, no action by the investigator or inquiry officer can expedite the process of obtaining evidence, but in some cases, the active conduct of the prosecution may hasten the process. Thus, when conducting ongoing covert investigative measures (for example, withdrawal of information from transport telecommunications networks), the investigator may try to establish when the person under supervision will report information relevant to the criminal proceedings on the phone. Alternatively, for example, when conducting examinations, the investigator may continue to look for samples that can be provided to the expert to expedite the investigation. The head of the body of inquiry or pre-trial investigation should assess all possibilities to expedite the pre-trial investigation and, if necessary, provide appropriate instructions to the investigator or inquiry officer;

3) whether the investigator (inquiry officer) could have avoided a situation in which he could not continue to carry out the procedural actions necessary for the investigation. In some cases, the results of the examination or other procedural action are key to the criminal proceedings, and such results will determine the further course of the entire criminal proceedings. However, this does not mean that the investigator or inquiry officer is obliged to delay the pretrial investigation until the relevant procedural steps have been completed in all cases. The head of the body of inquiry or pre-trial investigation must check whether the actual delay of the entire criminal proceedings due to other procedural actions is justified at the current stage of the pre-trial investigation. If it is established that the investigator (inquiry officer) unreasonably decided to delay the pre-trial investigation, although other procedural actions could have been carried out, the head of the pretrial investigation (inquiry) body will have to respond appropriately to the behavior of such authorized person, including deciding on his/her reassignment.

Thus, it can be concluded that first of all, when assessing the effectiveness of the pre-trial investigation, the head of the body of inquiry or pre-trial investigation should assess the number of procedural actions that have been carried out. Of course, such an approach to assessing the pretrial investigation effectiveness cannot be considered ideal. The assessment of effectiveness may vary significantly depending on the circumstances of the criminal proceedings, the complexity of the criminal offense, the requirements of the head of the inquiry or pretrial investigation, and so on. Furthermore, the pre-trial investigation effectiveness cannot be assessed using a single criterion, as such an approach rejects a number of other important factors that influence the course of criminal proceedings. However, taking into account the number of procedural actions as an assessment of the pre-trial investigation effectiveness has a number of strengths. First, this factor is purely objective. Accordingly, the subjective circumstances that can be taken into account by the head are leveled out in this case: personal relationship with the investigator (inquiry officer), his own vision of the pre-trial investigation effectiveness, and so on. In addition, the assessment of the number of procedural actions can be considered a good starting point for assessing the entire pre-trial investigation. If the investigator or inquiry officer has carried out a sufficient number of necessary procedural steps, but no results have been achieved, it is difficult to argue that such a pre-trial investigation is ineffective. Conversely, the small number of actions taken may be the first indicator of the need for closer scrutiny of the investigator's or inquiry officer's activities by the prosecutor and the head of the inquiry or pretrial investigation body. 


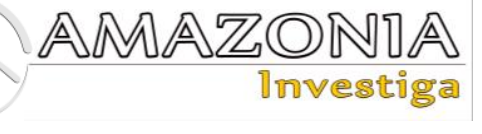

The lack of a pre-trial investigation is not an indication of its ineffectiveness. However, in this case, it is proposed to evaluate this approach differently: the presence of the result of the pretrial investigation indicates its effectiveness. Although such a position seems obvious, its analysis allows us to draw a conclusion about the normative consolidation of the pre-trial investigation effectiveness. In this case, it is proposed to use the legislative wording of the objectives of criminal proceedings. If the purpose of all criminal proceedings is to achieve the objectives provided in Art. 2 of the CPC of Ukraine (Law No. 4651-VI, 2012), the pre-trial investigation effectiveness should be assessed through the possibility of achieving such objectives. Accordingly, the pre-trial investigation effectiveness means achieving the objectives of criminal proceedings in accordance with Art. 2 of the CPC of Ukraine (Law No. 4651-VI, 2012). In addition, one of the key requirements that guarantees the implementation of these objectives is the clarity of legislation, which must be strictly adhered to at all stages of criminal proceedings.

Assessment of the provisions of Art. 2 of the CPC of Ukraine (Law No. 4651-VI, 2012) allows to conclude that the main task set before the investigator or inquiry officer during the pre-trial investigation is to identify persons who (probably) committed a criminal offense and to gather evidence sufficient to prove their guilt in court. The actual selection of such objectives allows us to argue about the need to distinguish between two stages of pre-trial investigation, which should assess the pre-trial investigation effectiveness: before and after notifying the person of suspicion. At the initial stage of the pretrial investigation, the investigator (inquiry officer) must carry out those procedural actions that will allow him to make substantiated notice of charges and hand it to the appropriate person. If such a notice has been served, it can be argued that the investigator (inquiry officer) has performed an intermediate task of the pre-trial investigation stage, which should be considered effective at this stage. There is a similar situation with the second stage, namely drawing up and sending to court a charging document. Accordingly, if the pre-trial investigation has gathered a sufficient set of evidence necessary to prove the guilt of a person in court, the work of the investigator (inquiry officer) can be considered satisfactory, and the pre-trial investigation itself - effective.

However, the investigator (inquiry officer) will not always have an objective opportunity to inform the person about the charges or send a charging document to court. The pre-trial investigation authorities are not tasked with sending a charging document to court in all criminal proceedings. The legislator emphasizes that only those persons who have committed criminal offenses should be prosecuted. The pretrial investigation may establish, for example, the absence of an event or the body of a criminal offense, which should entail the closure of criminal proceedings. Accordingly, a decision to close criminal proceedings (as well as a request to release a person from criminal liability or to apply coercive measures of a medical or educational nature to a person) is also an indicator of the pre-trial investigation effectiveness. At the same time, the effectiveness of the pre-trial investigation also presupposes its efficiency. Accordingly, the closure of the pretrial investigation by a decision to close criminal proceedings will only be an indication of an effective pre-trial investigation if such a decision was made in a timely and expeditious manner (not to mention the validity of such a decisionwhich must be checked by the prosecutor within twenty days from the date of the decision of the investigator or inquiry officer to close the criminal proceedings). However, it is necessary to establish in this case at what point the appropriate decision should be made in order to be able to assert the effectiveness of the pretrial investigation.

In this case, it would be appropriate to refer to the provisions of Art. 219 of the CPC of Ukraine (Law No. 4651-VI, 2012). The legislator quite clearly sets the terms of the pre-trial investigation both before and after the notification of suspicion. Accordingly, the extension of the pretrial investigation should first be acknowledged at the time of the inspection by the prosecutor, the head of the inquiry or pre-trial investigation body and, if necessary, the investigating judge of the pre-trial investigation effectiveness. The investigator (inquiry officer), when requesting an extension of the pre-trial investigation, must explain what procedural actions he has carried out, what still needs to be done to achieve the purpose of the pre-trial investigation and why they were not conducted in time. The fact of extension of the pre-trial investigation in itself should not be considered as an indicator of the ineffectiveness of the pre-trial investigation. However, it is at this stage of the pre-trial investigation that both the prosecutor and the head of the inquiry or pre-trial body should assess the quality and efficiency of the investigator's (inquiry officer's) work and, if necessary, respond to possible violations or 
delays by the investigator (inquiry officer) by providing instructions or even replacing one investigator (inquiry officer) by another one.

\section{The issue of effectiveness of the pre-trial investigation of corruption crimes by the National Anti-Corruption Bureau of Ukraine}

According to Article 216 of the CPC (Law No. 4651-VI, 2012), there are the following pre-trial investigation bodies available in Ukraine: investigative units of the National Police, security bodies, bodies supervising tax legislation, bodies of the State Bureau of Investigation and detective units of the National Anti-Corruption Bureau of Ukraine. From this list of law enforcement agencies, it can be seen that the detectives of the National AntiCorruption Bureau of Ukraine are the only body that investigates corruption crimes. However, taking into account the provisions of the note to Article 45 of the Criminal Code of Ukraine (Law No. 2341-III, 2001), corruption crimes are criminal offenses under Articles 191, 262, 308, $312,313,320,357,410$, in case of their commission by abuse of office, as well as criminal offenses under Articles 210, 354, 364, $364^{-1}, 365^{-2}, 368-369^{-2}$ of the Criminal Code of Ukraine (Law No. 2341-III, 2001). At the same time, the provisions of Part 5 of Article 216 of the CPC of Ukraine (Law No. 4651-VI, 2012) regulate the jurisdiction of the National AntiCorruption Bureau, indicating that detectives of the National Anti-Corruption Bureau of Ukraine conduct pre-trial investigation of criminal offenses under Articles 191, 206-2 $209,210,211$, 354 ( regarding employees of legal entities under public law), 364, 366 ${ }^{-2}, 366^{-3}, 368,368^{-5}, 369$, $369^{-2}, 410$ of the Criminal Code of Ukraine (Law No. 2341-III, 2001). When comparing the relevant articles listed in the Criminal Code (Law No. 2341-III, 2001) as corruption-related and those under investigation by the National AntiCorruption Bureau of Ukraine, it becomes clear that not all criminal offenses that the Criminal Code (Law No. 2341-III, 2001) defines as corruption can be investigated. However, even this incomplete list of criminal offenses is investigated by detectives under certain conditions.

Thus, not all corruption offenses are investigated by detectives of the National Anti-Corruption Bureau, some are investigated by other pre-trial investigation bodies. However, it is this body that investigates those corruption offenses that due to the presence of a special entity, which despite the main features of the subject of the offense has an additional one, namely holding a position, the list of which is enshrined in Part 5 of Art. 216 of the CPC and the presence of the established volume of the subject of the criminal offense, or if the damage caused by it and thus causes an increased public danger to the interests protected by law.

Given the fact that the National Anti-Corruption Bureau of Ukraine investigates the most socially dangerous corruption crimes, I consider it necessary to examine this pre-trial investigation body to assess the effectiveness of the investigation of corruption offenses.

First, it is worth highlighting approaches to understanding the effectiveness of the investigation of corruption offenses. We can define the following approaches:

- Economic approach assesses the effectiveness of the relevant body in terms of its impact on the economic situation in the country, given the clearly destructive impact of corruption crimes on the economic and financial system of the country. In this approach, two criteria should be distinguished: general economic-financial and specific economic-financial criteria. As for the general economic-financial criterion, it is comprehensive and should assess the impact of the activities of the relevant body on the economic and financial system of the country as a whole. There was no special research conducted regarding the impact of the National Anti-Corruption Bureau on the economic situation, however, for example, the official website of this agency lists one of the measures of the relevant law enforcement agency, which resulted in preventing illegal compensation of UAH 674 million from the state budget (National Anti-Corruption Bureau of Ukraine, 2021).The specific economic-financial criterion evaluates the effectiveness in terms of the amount received / returned or converted into state revenue as a result of the investigation, to the funds spent on financing the relevant body. It should be understood that the funds received / returned or converted into state revenue include both funds that constitute the amount of direct damage (for example, cash or valuables that constitute improper benefit) and those that constitute indirect / prospective damage (managed to save due to the cessation of illegal activities of the persons concerned). It is quite easy to determine the amount of direct damage; there are difficulties in determining the indirect damage, because, due to the possible nature of the offense, 


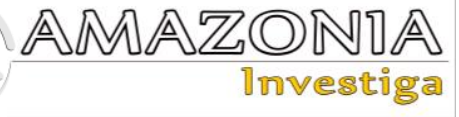

there is no exact way to calculate future possible direct damages from corruption crimes. The budget of the National AntiCorruption Bureau of Ukraine for 2020 amounted to UAH 890 million. Regarding the amount of returned / reimbursed funds by the relevant body, the National AntiCorruption Bureau noted in the report on its activities for the second half of 2020 that the estimated amount of damages caused by corruption crimes which are referred by law to the jurisdiction of the National Bureau and checked during the pre-trial investigation amount to UAH 293,384,015,420. However, the state and amount of compensation for damages and damages caused by criminal offenses referred by law to the jurisdiction of the National Bureau, amount to UAH $1,688,543,430$, incl. UAH $370,666,429$ in the second half of 2020. Nevertheless, the state and amount of compensation for damages and damages caused by criminal offenses, referred by law to the jurisdiction of the National Bureau, amount to UAH $1,688,543,430$, incl. UAH $370,666,429$ in the second half of 2020 (National AntiCorruption Bureau of Ukraine, 2020).

- Social approach assesses the impact of the relevant body on social life in the country. It is worth highlighting such a criterion as the corruption perceptions indexand public confidence in the relevant body. After all, the corruption perceptions index shows the attitude of society to corruption. The existence of a guaranteed inevitability of punishment is another element of the influence on distancing oneself from corruption and disclosing it to law enforcement agencies. Thus, according to a Transparency International report from the start of the National Anti-Corruption Bureau, Ukraine has slightly improved its corruption perceptions index, from 27 points in 2015 to 33 points in 2020 (the higher the score, the lower the level of corruption, from 0 to 100 points). However, 6 points in five years is a small result, which is not considered to be statistically significant(Transparency International Ukraine, 2020). As for the trust of citizens in the relevant body, according to sociological research conducted by the Razumkov Center, as of July 2020 we have the following figures: $37.7 \%$ do not trust it at all, $33.4 \%$ rather do not trust, $10.7 \%$ rather trust, $1.7 \%$ trust fully, and $16.6 \%$ have difficulty answering(Citizens' assessment of the situation in the country, the level of trust in the executive and law enforcement agencies, the assessment of the Government's activities (sociology as of February 2020 by Razumkov Center (2020)).

- Criminal procedural approach evaluates the activities of the relevant bodies through the prism of compliance with the work of the relevant body to the tasks of criminal proceedings, which are specified in Art. 2 of the CPC of Ukraine (Law No. 4651-VI, 2012). Depending on the specified objectives, it is necessary to allocate also corresponding criteria of an estimation of effectiveness. Thus, the tasks of criminal proceedings are:

- Protection of the individual, society and the state from criminal offenses is a criterion that assesses the overall impact and characterizes the direction of law enforcement. Thus, in 2020, 792 criminal proceedings were initiated, and 201 persons were reported as suspects and from 2015 to December 21, 2020, the National AntiCorruption Bureau sent 300 charging documents to court against 541 defendants. And in the second half of 2020, detectives of the National Anti-Corruption Bureau of Ukraine sent 35 charging documents to court, against 56 defendants. Among them: 7 senior state officials, 2 civil servants, "A" category local government officials, 1 judge (National Anti-Corruption Bureau of Ukraine, 2020).

- Protection of the rights, freedoms and legitimate interests of participants in criminal proceedings is a criterion designed to ensure the principle of legality in criminal proceedings. In exercising their powers, the relevant law enforcement agencies should give priority to the protection of the rights, freedoms and legitimate interests of participants in criminal proceedings. This criterion can be assessed based on the number of satisfied complaints about the actions of employees of the relevant law enforcement agency, which violate the rights, freedoms and legitimate interests of participants in criminal proceedings. Thus, according to the report of the Internal Control Department of the National Bureau, 550 appeals and complaints were received against the employees of the National Bureau in 2020, 8 official investigations were conducted in the same reporting year, 7 people were prosecuted (which resulted in 2 reprimands, 3 remarks and 2 dismissals) against 236 full-time detectives and 504 fulltime employees of the National Anti-Corruption Bureau of Ukraine 
(National Anti-Corruption Bureau of Ukraine, 2020).

- Ensuring efficient, complete and impartial investigation and trial is a criterion that directly characterizes the "quality" of the performance of their functions by law enforcement agencies. However, this criterion is evaluative, because the implementation of each component depends on many evaluation factors. For example, the investigation of the criminal proceedings, which in the report of the National Agency is noted as: the seizure of gas by Naftogaz Ukraine lasted 42 months. During this time, more than 30 searches, 30 forensic examinations, 100 interrogations, 50 inspections, 20 temporary accesses to things and documents were performed, and 250 volumes of criminal proceedings were formed; the amount of losses is UAH 729.8 million (National Anti-Corruption Bureau of Ukraine, 2020)

- Everyone who has committed a criminal offense has been prosecuted to the extent of his or her guilt; no innocent person has been charged or convicted. This is a criterion that also characterizes the "quality" of law enforcement functions in relation to reasonable suspicion and sentencing of a person. Regarding the quality of the pre-trial investigation, in 2020 the Supreme AntiCorruption Court of Ukraine passed 20 convictions against 23 people, while no acquittals were issued in 2020. Among the convicts, there are former people's deputies, heads of state-owned enterprises, officials, judges, lawyers and others. As of the end of 2020, 175 cases under investigation by the bureau are pending before the court (National Anti-Corruption Bureau of Ukraine, 2020).

- No person has been subjected to unreasonable procedural pressure. This is a criterion for the proper implementation of the presumption of innocence. It should be assessed by the number of canceled procedural documents that provided for procedural pressure. Thus, in the first half of 2020, the Supreme Anti-Corruption Court granted $80 \%$ of motions to select precautionary measures for suspects, and in $75 \%$ of cases, judges decided to detain persons convicted of corruption (National Anti-Corruption Bureau of Ukraine, 2020).

- Each participant in the criminal proceedings was subject to an appropriate legal procedure. This criterion is decisive for the admissibility of evidence and is designed to ensure the implementation of the form of criminal proceedings, and is assessed by the amount of evidence that was declared inadmissible.

\section{Conclusions}

The standards of the investigation effectiveness, which were developed by the ECHR in the context of Art. 2 and Art. 3 of the Convention for the Protection of Human Rights and Fundamental Freedoms are of such a nature that at the present stage of development of positive obligations of states can not only affect the investigation of death and ill-treatment. Duty to take action; ex officio response; preservation of evidence; efficiency and reasonable speed; good faith (diligence); impartiality; accessibility to the public and stakeholders (particularly victims) should be used in assessing the investigation of any criminal offense. In part, these standards are taken into account in Art. 2 of the CPC of Ukraine (Law No. 4651-VI, 2012) through the task of efficient, complete and impartial investigation.

It can be concluded that the pre-trial investigation effectiveness is a feature of the pre-trial investigation, which is characterized by the ability to achieve the objectives provided for in Art. 2 of the CPC of Ukraine (Law No. 4651-VI, 2012), and which can be assessed by checking the number of objectively necessary procedural actions and efficiency of intermediate and final procedural decisions (notification of suspicion, drafting and sending a charging document to court, closing criminal proceedings, etc.).

The National Anti-Corruption Bureau of Ukraine was established in 2015. It is the central body of pre-trial investigation, which investigates the most socially dangerous corruption crimes. To assess the effectiveness of its work, one can use different criteria as well as different approaches to the effectiveness criteria. However, it is safe to say that the relevant body is working more effectively every year, as evidenced by the annual increase in the number of criminal proceedings investigated by the relevant body; charging documents sent to court; the amount of damage reimbursed to the state; relatively small number of judges refusing to apply precautionary measures; relatively small number of substantiated complaints and statements about the actions of bureau employees, etc.

\section{Bibliographic references}

Akhtyrska, N.M., Kasko, V.V., Malanchuk, B.A., Melikian, A., Poshva, 


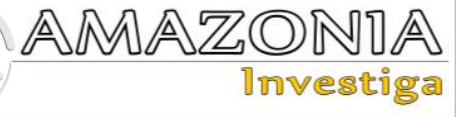

B.M., Fulei, T.I., \& Shuklina, N.H. (2011). Application of European standards for combating ill-treatment and impunity in Ukraine: a scientific and practical guide for judges. Kyiv: "K.I.S". Recovered from http://www.nsj.gov.ua/files/1445846131Man ual\%20judges\%20block\%20FINAL.pdf

Bielousov, Yu., Hatiiatullin, O., Zaporozhtsev, K., Tarasova, M., \& Shurduk, V. (2018). Research "Recording and investigation of torture in places of detention. Analysis of legislation" (2018). Recovered from https://ecpl.com.ua/wpcontent/uploads/2018/11/Fiksatsiia-tarozsliduvannia-katuvan-.pdf

Burbelo, B.A. (2015). Basics of methods of crime investigation, related to corruption. Bulletin of luhansk State University of internal affairs, 2. 233-239. Recovered from: https://journal.lduvs.lg.ua/index.php/journal/ article/download/699/630/

Case of Kaverzin v. Ukraine, Application № 23893/03, Decision of the European Court of Human Rights, 15 May 2012. Recovered from

https://hudoc.echr.coe.int/rus\#\{\%22fulltext \%22:[\%2223893/03\%22],\%22documentcoll ectionid2\%22:[\%22GRANDCHAMBER\%2 2,\%22CHAMBER\%22], \%22itemid\%22:[\% 22001-110895\%22]\}

Case of Kholodkov and Kholodkova v. Ukraine, Application № 29697/08, Decision of the European Court of Human Rights, 07 May 2015. Recovered from https://hudoc.echr.coe.int/eng\#\{\%22fulltext \%22:[\%2229697/08\%22],\%22itemid\%22:[ $\% 22001-154160 \% 22]\}$

Case of Yaremenko v. Ukraine, Application № 32092/02. Decision of the European Court of Human Rights, 12 June 2008. Recovered from

https://hudoc.echr.coe.int/rus\#\{\%22fulltext \%22:[\%2232092/02\%22],\%22documentcoll ectionid2\%22:[\%22GRANDCHAMBER\%2 2,\%22CHAMBER\%22],\%22itemid\%22:[\% $22001-86885 \% 22]\}$

Chernobaiev, S.I. (2020). Powers of the investigator during the pre-trial investigation (doctoral thesis). National Law University in the name of Yaroslav the Wise, Kharkiv. Recovered

fromhttp://nauka.nlu.edu.ua/download/diss/ Cernobaev/d_Cernobaev.pdf

Danyliuk, M.I. (2011). Subsequent stage of investigation of corruption crimes. Scentific bulletin Lviv State University of internal affairs, 1 (2). 293-299. Recovered from: http://www.lvduvs.edu.ua/documents_pdf/vi snyky/nvsy/01_2011_2/dmirkz.pdf
Hloviuk, I.V. (October 19, 2016). Article 206 of the CPC of Ukraine and the investigation of ill-treatment (in the context of Article 3 of the Convention for the Protection of Human Rights and Fundamental Freedoms. Crime prevention: theory and practice: materials of the $7^{\text {th }}$ All-Ukrainian scientific and practical conference (October 19, 2016). Kyiv: National Academy of the Prosecutor's Office of Ukraine, 2016, 181-186.

Hnatovskyi, M., Bielousov, Yu., Shvets, S., Venher, V,. \& Bondarenko, O. (2016), Research "Implementation of international standards in the field of prevention of illtreatment in the activities of criminal justice bodies of Ukraine" (2016). Recovered from https://ecpl.com.ua/wpcontent/uploads/2019/03/Implementatsiyamizhnarodnyh-standartiv-u-sferizapobihannya-nenalezhnomupovodzhennyu-v-diyalnist-orhanivkryminalnoji-yustytsiji-Ukrajiny.pdf

Hovorun, D.M. (April 29, 2013). Effective pre-trial investigation as a means of implementing the principle of publicity in criminal proceedings. Prospects for the development of pre-trial investigation: procedural organizational aspects: materials International scientific and practical conference (Luhansk, April 29, 2013), 215-258. Recovered from http://dspace.nlu.edu.ua/handle/123456789/1 1037.

Korcheva, T.V. (2019). The effectiveness of pre-trial investigation: definition. Comparative and analytical law, 6, 460-464. Recovered from: https: //doi.org/10.32782/2524-0390/2019.6.116.

Kymlyk, N.V. \& Kymlyk, R.V. (2014) Crime investigation related to corruption. Internationak Legal Bulletin: a collection of scientific proceedings of the National State University tax service of Ukraene, 1, 102-107. Recovered from: http://irbisnbuv.gov.ua/cgi-

bin/irbis_nbuv/cgiirbis_64.exe?C21COM=2 $\& I 21 \mathrm{DBN}=\mathrm{UJRN} \& \mathrm{P} 21 \mathrm{DBN}=\mathrm{UJRN} \& \mathrm{IMA}$ GE_FILE_DOWNLOAD=1\&Image_file_na me=PDF/muvnudp_2014_1_18.pdf

Kymlyk, N.V. \& Kymlyk, R.V. (2017). Investigation of corruption criminal offenses in the aspect of compliance human rights and citizen. Internationak Legal Bulletin: a collection of scientific proceedings of the National State University tax service of Ukraene, 1, 98-103. Recovered from: http://www.irbis-nbuv.gov.ua/cgibin/irbis_nbuv/cgiirbis_64.exe?C21COM=2 $\& I 21 \mathrm{DBN}=\mathrm{UJRN} \& \mathrm{P} 21 \mathrm{DBN}=\mathrm{UJRN} \& \mathrm{IMA}$ 
GE_FILE_DOWNLOAD=1\&Image_file_na me=PDF/muvnudp_2017_1_18.pdf

Law No. 2341-III. Criminal Code of Ukraine.Vidomosti of the Verkhovna Rada of Ukraine, Kyiv, Ukraine, September 11, 2001. Recovered from https://zakon.rada.gov.ua/laws/show/234114\#n89.

Law No. 3477-IV. On the implementation of decisions and application of the case law of the European Court of Human Rights. Bulletin of the Verkhovna Rada of Ukraine, Kyiv, Ukraine, July 28, 2006. Recovered from

https://zakon.rada.gov.ua/laws/show/347715\#Text

Law No. 4651-VI. Criminal Procedure Code of Ukraine. Bulletin of the Verkhovna Rada of Ukraine, Kyiv, Ukraine, April 13, 2012. Recovered from https://zakon.rada.gov.ua/laws/show/465117\#Text.

Lazukova, O.V. (2018). Special regime of pretrial investigation in the conditions of martial law, state of emergency or in the area of antiterrorist operation (doctoral thesis). National Law University in the name of Yaroslav the Wise, Kharkiv. Recovered from: http://nauka.nlu.edu.ua/download/diss/Lazuk ova/d_Lazukova.pdf

National Anti-Corruption Bureau of Ukraine (2020). Report: second half of 2020. Recovered from https://nabu.gov.ua/report/zvit-drugepivrichchya-2020-roku

National Anti-Corruption Bureau of Ukraine (2021). NACB together with the SFS and the STS prevented illegal reimbursement of VAT in the amount of UAH 674 million. Official site of the National Anti-Corruption Bureau of Ukraine. Recovered from: https://nabu.gov.ua/novyny/nabu-spilno-zdfs-ta-dps-unemozhlyvyly-nezakonnevidshkoduvannya-674-mln-grn-pdv.

Razumkov Center (2020). The beginning of a new political year: trust in social institutions
(July 2020). Official website of the Razumkov Center. Recovered from https://razumkov.org.ua/napriamky/sotsiolog ichni-doslidzhennia/pochatok-novogopolitychnogo-roku-dovira-do-sotsialnykhinstytutiv-lypen-2020r

Sichko, S.O. (2021). General provisions of the pre-trial investigation (doctoral thesis). National Law University in the name of Yaroslav the Wise, Kharkiv. Recovered from http://nauka.nlu.edu.ua/download/diss/Sichk oS/a_SichkoS.pdf

Stetsenko, Yu.V. (2018). Effective pre-trial investigation: the meaning of the concept. Scientific Bulletin of Uzhhorod National University. Law Series, 49, 2, 126-129.

Transparency International Ukraine (2020). Corruption Perceptions Index - 2020. Recovered from https://tiukraine.org/research/indeks-spryjnyattyakoruptsiyi-2020.

Zelenetskyi, V., \& Loboiko, L. (2009). Criteria for assessing the effectiveness of criminal prosecution in Ukraine. Legal sciences of Ukraine (Collection of scientific works). Recovered from http://www.infolibrary.com.ua/books-text-10081.html.

Zhidkov, V.L. (2019) Criminal-procedural activity of the detective of the National AntiCorruption Bureau of Ukraine (doctoral thesis). National academy of internal affairs. Kyiv. Recovered from: http://elar.naiau.kiev.ua/jspui/bitstream/1234 56789/15737/1/dis_zhydkov_vl.pdf

Zhuravel, V.A. \& Reznikova, O. I. (2017). Forensic understanding of crimes corruption. Innovative principles technical and criminal provision of activites bodies of criminal justice (monograph). Kharkiv, 157-171. Recovered from: https://dspace.nlu.edu.ua/bitstream/1234567 89/14678/1/Guravel_Reznikova_157171.pdf

Znikin, V.K. (2014). Some issues of the effectiveness and quality of pre-trial proceedings. Criminal Justice, 1 (3), 20-24. 